\title{
Feature Film Script Writing Quality Issues: KL Vampires Film (2019)
}

\section{Nurhafizah Binti Kamarudin, Ahmad Azlan Syah Bin Abd Rashid}

To Link this Article: http://dx.doi.org/10.6007/IJARBSS/v11-i11/11532

DOI:10.6007/IJARBSS/v11-i11/11532

Received: 13 September 2021, Revised: 10 October 2021, Accepted: 27 October 2021

Published Online: 07 November 2021

In-Text Citation: (Kamarudin \& Rashid, 2021)

To Cite this Article: Kamarudin, N. B., \& Rashid, A. A. S. B. A. (2021). Feature Film Script Writing Quality Issues: KL Vampires Film (2019). International Journal of Academic Research in Business and Social Sciences, $11(11), 362-371$.

\section{Copyright: (c) 2021 The Author(s)}

Published by Human Resource Management Academic Research Society (www.hrmars.com)

This article is published under the Creative Commons Attribution (CC BY 4.0) license. Anyone may reproduce, distribute, translate and create derivative works of this article (for both commercial and non-commercial purposes), subject to full attribution to the original publication and authors. The full terms of this license may be seen at: http://creativecommons.org/licences/by/4.0/legalcode

Vol. 11, No. 11, 2021, Pg. $362-371$

Full Terms \& Conditions of access and use can be found at http://hrmars.com/index.php/pages/detail/publication-ethics 


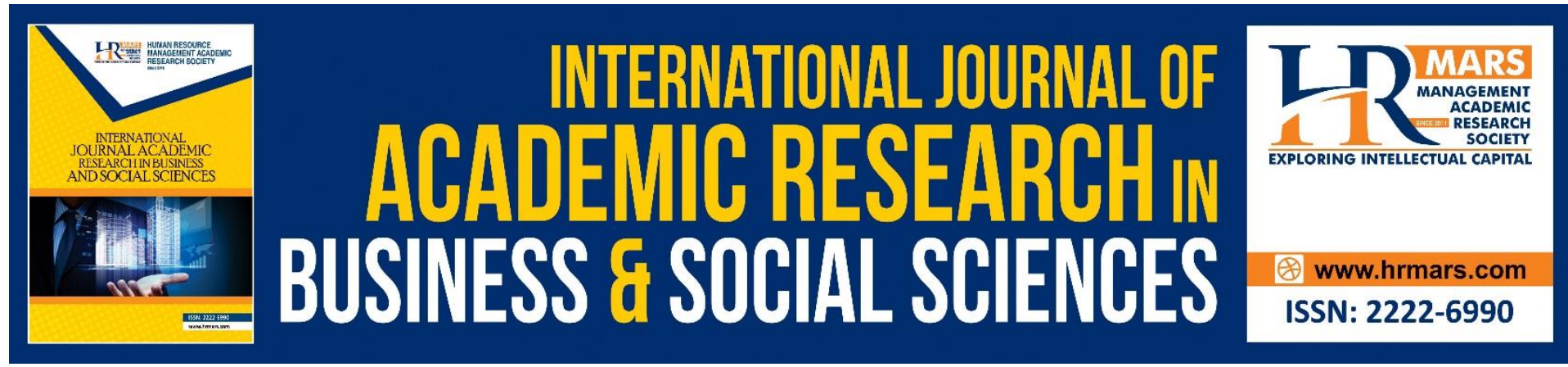

\title{
Feature Film Script Writing Quality Issues: KL Vampires Film (2019)
}

\section{Nurhafizah Binti Kamarudin, Ahmad Azlan Syah Bin Abd Rashid}

Faculty of Film, Theatre and Animation, MARA University of Technology

Email: nhnurhafizah641@gmail.com, azlan696@uitm.edu.my

\begin{abstract}
The recent production of feature films in Malaysia has shown positive development in terms of cinemas collection. However, there are some of the feature films made per year that fail on cinemas collection due to poor film script that does not meet the expectation of the local audience. There are a few good film scripts that is also not successful on cinemas. The importance of the research on script writing quality issues is necessary to find a solution to bring Malaysia films to a higher level and international level. The main findings of this study will unravel the reasons why this is still happening when the quality of some of the film scripts is very good. This is due to the acceptance of film audience in Malaysia who are given less exposure to the aesthetics of a film artwork in general. Therefore, successful films in Malaysia are more of mere entertainment and films are not considered as a medium that can change the ideology of a society. The research method used is qualitative through interviews with the director and scriptwriter of KL Vampires (2019) film and descriptive secondary data through articles and books. Studies on feature film scriptwriting in Malaysia in the future should focus more on issues on how history, culture and heritage can be preserved through film with quality film scriptwriting.
\end{abstract}

Keywords: Script Writing, KL Vampires Film, Filmmaking

\section{Introduction}

The advent of advanced technology in global filmmaking to some extent influenced the Malaysia film industry to keep pace with the global progress mainly in Southeast Asia. Although the country's film industry is progressing, especially in terms of editing and revenues collection, the film industry is still facing various problems. There are some great films that have a good storytelling plot but failed on the revenues collection. Malaysia film industry high collection films are dependent on the popularity of actors, directors, and producers. The film KL Vampires (2019) is one of the less popular local films in Malaysia (Gempak, 2019). Therefore, this article emphasize on low revenues collection that have quality from the aspect of script writing. KL Vampires (2019) cinema collection from the information obtained from the main informants, Daven Raghavan (Film Director)/Nazri M. Annuar (Script Writer) was less than RM 100,000 and Astro First's collection was only RM 250,000. Based on this low collection, are there any issues that interfere with quality in script writing even though $K L$ 
Vampires (2019) received several compliments on the script mainly that express their appreciation on the Raja Bersiong old Malay folklore, The Vampire King.

Script writing is very important because the writer needs to ensure that the work is quality and acceptable to the audiences. Researchers agree that producing quality feature film script is not a very easy thing compared to writing a literary work. The script writer needs to move the prose into the form of dialogue and imagine each visual element that wants to be highlighted in the screenplay (Latifah, 2016). However, quality film scripts can be beneficial in practice and can help change the standard of script writing to a higher level. In this article, the researchers will examine the problem of lack of quality script i.e. undeveloped story idea, profit or pleasure rather than producing a good story quality, script filled with non -universal conflict, audience lack of understanding in film narrative value and wrong script visualization by the film directors and actors. This problem has contributed to the lack of quality scripts in Malaysia. So, the researchers gave the view that the problem needs to be solved to help the film script writers in preparing to generate quality script. The researcher hopes through this article, to be able to open mind and space for scriptwriters to maintain quality in script writing and work is valued.

\section{Analysis and Discussion}

This study was conducted to clarify the research questions regarding the problem of lack of quality scripts in films in Malaysia, the role of writers in producing quality scripts and the importance of quality script writing values. Analysis and discussion of the study will link correlations with theory, past studies, and information results from interviews. Each analysis performed by the researcher facilitates to understand the details of the study and identify each issue raised.

\section{Feature Film Scripts in Malaysia Lack of Quality (The Problem in KL Vampire Film Script)}

Overall, informants say that script quality is very important in the film world. Through interviews, informants said there were various problems they received throughout their service in the film industry. This problem stems from a variety of factors that can affect the quality of a film script. Among the problems they received were weakness in terms of acting skills and acting according to the characteristics of the characters.

Weak problems in terms of acting skills can have an impact on a film. The process of acting involves an individual skill such as an act or action defined in Gage's Canadian Dictionary. These will act to bring the character to explore the interpretation of life and become someone else for a while (Cameron, 2020). This process is an actor's skill that needs to be applied in order for the character to succeed and to be able to provide understanding to the audience. Being an actor is not an easy task as they need to express skills through various behaviours such as feelings, speech, use of body language and provoking facial reactions. If the acting skills are lacking it will show the weakness of the actor to recognize the characters in the script. The weakness affects the quality of the scripts because they are not able to make the interpretation of the characters and the depiction of the movement of the story formed by the script writer. An actor's skill is an act of delivery that needs to be realistic or look real to illustrate the entire content of the story. Therefore, every film release, the production team is encouraged to hold a casting to see the situation and find the right actor to bring the required character. Based on informants, the selection of actors is difficult on some specific characters. At the casting event there were actors who lacked depth of 
feeling and did not understand the characters needed in the script. They just came to the event to try their luck. However, there are also some actors who almost animate the character but they fail to stand out. The researcher's argument is that when doing the casting, they can see broadly in terms of the shortcomings in each character. Therefore, the script writers had to find a solution by changing their script to look suitable for the actor. If the acting skills are less, of course the quality of the script will be less because it is not in line with the character delivery. Each character in the script depicts a visual in a screenplay (Mcgibbon, 2014). So, every actor needs to maintain the visuals in the script to the screenplay in order to highlight the appeal and quality of the script writing.

At the casting selection event of $K L$ Vampire film, actors have the equipment in terms of appearance and ability to bring a fighting scene on a particular character according to the depiction in the script. However, acting skills are lacking and many scenes do not reach the audience. This lack of skill has disturbed the tone in the dialogue. The tone of the actor determines the audio picture, the type of dialogue and the visuals of the characters for a film. Although the tone can be edited, but it can affect the actors and the film. The change will not look like the real situation and will only bring down the reputation of the actor. The visuals formed by the scriptwriter will also not reach the screenplay. Mcgibbon's (2014) theory, dialogue is a depiction of the visual form of a script before it becomes a complete film. Reviews of the researchers, the character who casts the dialogue will determine the delivery of the quality script or vice versa. This is because it is the dialogue that will form a complete story through feelings, understanding and explanation of the situation.

The problem, lack of quality in film script is also related to following audience's tastes of the story and the characters. Humans are beings who have minds so they are easily influenced by the environment. Similarly in the field of film industry, the audience is easily influenced by the produced film works so that everyone has a different taste of the story. Researcher's argument, KL Vampire film has its own fans. Still, the audience citations don't determine the quality of a story or the overall feature film. The quality factor has many branches in the feature film e.g. Screenplay, Cinematography, Production Design, Editing, Acting and Directing that compliment each other to bring out the best visual derived from the film script.

The choice of film depends on the desire of the audience as the right of the customer to watch the film or vice versa. There is an analysis of a study by Zhu (2019), saying a film is good and bad depending on the evaluation or choice of the audience. The researcher Zhu found a shortcoming in his study because the audience selection caused the script quality to decrease in Malaysia. They stipulate that only the audience is the recipient of film mass communication. Such a perception only causes the factor of lack of quality script writing work and artistic elements difficult to be appreciated. Based on the interviews, it was found that the informants were satisfied with the quality of local film script writing. However, the problem on the lack of quality script is in terms of the tastes of the audience which differ from the needs of the script. In Malaysia, scriptwriters and producers need to look at the tastes of the audience and the types of stories they can watch. The researcher's argument, the film industry establishes that audience tastes determine the success of revenues collection and film was treated as entertainment item solely not because of the narrative artistic value of the story. This explains that the audience is limiting the quality of local film script writing. 
Script writers ideas are also limited to producing quality work because their tastes are the same thing and don't change. In this section, the researcher can see that the development to advance in script writing is quite difficult because the film script must be determined through the tastes of the audience. This factor causes the problem of the poor quality script that the writing work is not appreciated by the audience because it is not open to understand the narrative artistic value of the film.

\section{The Role of The Script Writer in Producing a Quality Feature Film Script}

The quality of script writing is seen in various forms or roles of writers as they are the ones who will determine the issue of lack of quality in script writing. When involved in the script writing process, there will be an expansion of the story to realize the film script in a specific context. Among the writer's roles are efficiency, a lot of reading and watching international movies.

Every individual needs to have a role of competence in themselves to produce quality work. In the film industry, there will be progress initiatives in producing good works (Kathryn, 2010). The initiative is through discussions that form a series and create the illusion of the film. Through discussion, they will gain a lot of information about all the scene -by -scene processes, characters, edits and storyline. On that part, they can correct errors or omissions in script writing. This competency has clarified a writer's responsibility in producing quality scripts and planning new looking work ideas. When competence is not in the self it will give problems for the writers to face progress. This is because writers are unable to push themselves to compete in the film industry. The competence of the script writers will reflect their success in producing good work. It depends on one's thinking or role in thinking to advance the film script writing industry.

Quality can result when the scriptwriter has a role with a lot of reading and watching international films. The film industry is so advanced that there are many competitors between local and foreign filmmakers. To make progress in the film industry, informants encouraged change. As an artist, it is necessary to refer and emulate the success of external artists. If this role is not in the writer, it will give difficulty in building quality writing. When writers read a lot, they indirectly learn the basics of storytelling, new concepts and ideas. The researcher's argument, the task of script writing is to share a story that helps the audience understand the world of scriptwriter design. Without these factors, script writing will be less satisfactory. Thus, the quality of the story will also not be formed until there is a lack of interesting ideas. This role can develop new ideas and have the inspiration to create.

Besides to watch international films, the informant suggested that local script writers need to watch a lot of various genres of international films and understand every detail or artistic element in the film. In the opinion of researchers, many younger generations prefer to watch foreign movies than local ones. All films have different uniqueness and appeal. Therefore, viewers are easily attracted to international films because of their own uniqueness. So, the researchers comment is that the scriptwriter needs to know the elements that attract this generation from watching the film. With that observation can give impetus and help the writer create ideas and create other attractions for the local audience. 


\section{The Importance of Quality Values of Scriptwriting in Filmmaking}

Every individual action has a value that can bring about the success of a superior human being. In the field of script writing also need to have certain values to produce quality in the film work. These values give importance to human beings in shaping human beings in terms of culture, knowledge, social interaction, creative thinking, emotions, and feelings. According to Norasiah (2018), every value in a person will not be able to satisfy all parties. The researcher's argument is undeniable that the values to satisfy all parties are very difficult. This is because every human being has a different way of life. It depends on the individual who wants to make a change in themselves. However, the importance of these values is seen as a positive development to advance the quality of script writing in filmmaking. Among the importance of values are critical thinking, looking at the world of the environment and exposure to artistic values.

Critical thinking is a value capable of creating quality film script writing. The film industry needs a competition of imaginative and creative thinking. Critical thinking means someone who is involved in evaluating, observing, and developing their skills clearly to create. If they do not practice critical thinking will give a weak factor in forming a quality script. This makes thinking skills an element that gives major importance and emphasis in script writing. This importance greatly helps the writer make an interpretation of the creative ideas on the script before it becomes a form of blueprint on the film screenplay. According to Tomaric (2013), if the blueprint is not on the script page, it will not succeed on the cinemas. The researcher's argument, the blueprint will meet the content of the story, characters, dialogue, and the situation of the scene to form a complete story. The story will depict the real life of the story. Thus, each element can help produce different creative skills and give importance to the quality values of scriptwriting in filmmaking. To come up with interesting ideas, every human being needs to have the value of critical thinking in a planned manner. It can be done through thinking, reading, seeing, listening, and writing skills (Peng et al., 2014). The researcher's argument is to give the importance of lifelong knowledge to individuals to think critically and creatively in their work. The value of critical thinking is not just for the script writer alone, the audience can also influence those skills through their understanding of a film. Based on the $K L$ Vampires film, there are artistic elements that have been highlighted by the script writer. However, the lack of understanding from the audience has made the script writing factor fail in quality therefore the film flop in the local cinemas. Therefore, the writer needs to highlight the structure of the critical elements in the script. This is because the audience can follow the thinking and give opinions according to the situation, interpretation of artistic elements and summary of the story appropriately. The importance of these values can develop creative-minded scriptwriters and motivate the audience. Audiences who successfully understand the content of the element will appreciate the importance of the value seen and exemplified.

Seeing and observe the world in different forms and unique environment is also a value of importance to the script writers to produce an imaginary world logically. Each story that is formed will have a specific goal that the scriptwriter wants to convey. Thus, the writer is responsible for building the script, the world, and each character in the script into a complete story. Meaning, the writer needs to build the script well so that it doesn't look fake and can be accepted by the audience. When they see the world, the environment will be able to visualize the movement of the story world. The world is an environment that will teach, 
guide, and encourage writers in building the value of writing. This gives them an awareness that each individual has a different way of life. Therefore, writers need to practice those values to help writers to be in the script. The environment provides a picture of human experience that conveys a story about oneself, others, or the story of a fictional world (Xu et al., 2011). The researcher's argument is that this environment can enrich the author's ideas and experiences. This is because they can see the different types of life stories experienced by the community. This process will provide impetus to scriptwriters as they tend to understand ideas, concepts and gather more complex information for their scripts. This value gives strength to the success of scriptwriter in producing quality work. As a film industry script writer, it is necessary to open eyes and minds in terms of observations to see the unique world around them. They need to improve their higher and learning thinking skills and accept the lives of others as learning to produce film script works as real as possible (even if it is a fiction narrative). Involved in the creation, the writer needs to have great experience and openness of mind so that the story looks interesting. The action is again easy for the interested audience to understand the course of the story. Although the main purpose of storytelling is to convey a story, but writing is also important to form quality values.

Exposing the value of artistic art in filmmaking can raise the importance of the quality of script writing. There is no denying that society in Malaysia lacks exposure to the value of artistic art. The informant's perception of the community in Malaysia is more towards the world of education than towards the world of art. The researcher's argument is that the younger generation in school is already applied towards higher education. Therefore, they are less aware of artistic values whereas in the film there are artistic values that are highlighted to the audience. In film, artistic art aims at the expression of an artist to highlight the superiority of sublime creativity. Therefore, every creator will have a goal to produce a film. Similarly with scriptwriters, they have a mission, goal and a vision of artistic value that they want to show to the audience through their scripts (Tregde, 2013). The researcher argues that the writer can show various types of characteristics in script writing to produce a value. The value of this script can form a complete visual appearance based on the artistic and style that will be used by the editors. Artistic value can be formed through structure, scene arrangement, character, or story tension (Yang, 2019). Each of the values highlighted needs to be real and understood by the audience. However, Malaysians only watch movies just to entertain and satisfy them. Thus, the emergence of the factor of lack of quality script because the audience does not know in depth about artistic values. While this value exists to cultivate the creativity of better writing ideas. In the local film industry, script writers have endeavoured to produce expressions of thought, material, context, and technique within the script so that the artistic values reach out to the audience. However, the audience in Malaysia still does not understand the value of the art. This value needs to be shown to the audience so that script writing can be the impetus to write a better quality script. This is because writers want their work to be appreciated and the audience to be able to understand the elements of art. If they do not understand, then the quality is less produced because it is not in line with the audience's understanding of the artistic value element of the script. Therefore, exposure needs to be done to transform the local film industry. When the audience is exposed to the importance of artistic value in film it will improve the quality on local film script writing.

\section{Conclusion}

Overall, a study was conducted to look at the issue of scriptwriting quality in the success of a KL Vampires (2019) film. The findings of the study showed that the script writers were 
satisfied with the work of writing the film script. However, the quality is less prominent because there are various problems that arise so that there is a lack of quality in the script writing. The results of the study found that the issue of script writing quality did not occur entirely from the script writer, resulting in poor quality scripts. There are other parties involved that even dictate the script writer to produce a good quality script. Provision for change will exist if the scriptwriter and the production team work together to make improvements to the scriptwriting. The quality of the script has a different understanding based on the length of experience of the script writer in the film industry. This is because a quality film consists of various types of branches to complement that quality. However, the audiences need to be aware that the script is also one of the factors that contributes to the quality of the film. So, each party needs to work together to complete to one goal to make a quality film a success. This is an appropriate action in the interest of audiences. The process can increase the community's understanding of the quality of local film work. In fact, each value indicates that they have achieved goals and objectives based on the results of preproduction discussions on the film. They need to always focus on the goals that have been set to achieve the importance of script writing quality.

The final product delivery of the KL Vampires (2019) story has elements of twists and turns compared to other films. Although the $K L$ Vampires film collection is less than satisfactory but the elements highlighted benefit the scriptwriters to get the motivation to produce better work and new ideas. Situations like this give a feeling to the scriptwriter to continue to struggle to carry out the responsibilities as a scriptwriter. Although film scripts have a lack of quality, but they can learn to improve the writing in a better direction and become a quality work. The progress of script writing will be further developed and appreciated. The audience should also pay tribute to the scriptwriter. This appreciation is audience feedback to the success of the scriptwriter. So, the audience should understand certain stories and messages in more depth than mere entertainment and fun. In Malaysia, there have been changes in scriptwriting but not to the audience who still find it difficult to understand an art in film. As a result of the researcher's observation, this artistry is closely related to quality to increase the productivity and quality of the film script. If the audience understands and appreciates the script it can indirectly raise the name of the film with quality writing. Every study done has significance for readers daring to make changes. Significance is important in contributing to a particular policy or aspect. Research is done to develop knowledge in an area of expertise or explore new areas. In this essay, the significance that can be gained is to make each framework an investment in film script writing. The framework helps to bring about change in a person to advance oneself in a field especially film script writing.

\section{Corresponding Author}

Ahmad Azlan Syah Bin Abd Rashid

Faculty of Film, Theatre and Animation, MARA University of Technology Malaysia

Email: azlan696@uitm.edu.my

\section{References}

Mohaideen, A. R. H., \& Abu Bakar, M. S. (2018). Meneroka Permasalahan Tenaga Modal Insan dalam Industri Filem di Malaysia. Forum Komunikasi,13(1), 41-56.

Wahab, A., Ajagbe, A. A., \& Abu Talib, N. (2013). Malaysian Film Projects Network 
Mobilization. Journal of Social and Development Sciences. AMH International, 4(2), 6168.

DOI: $10.22610 /$ jsds.v4i2.736

Badr, A. (2011). Quality- General Concept and Definitions. 1-13. https://www.researchgate.net/publication/221919328_IAQuality_General_Concepts_and_Definitions

Cameron, R. (2020). Acting skills for life: third edition. Ebook Infinity. 1-23. http://infinity.wecabrio.com/889242895-acting-skills-for-life-third-edition.pdf

Gempak. (2019). Throwback Gempak 2019: 10 filem melayu yang tidak mendapat sambutan di pawagam. Astroawani.com.

https://www.google.com.my/amp/s/www.astroawani.com/beritahiburan/throwbackgem pak2019-10-filem-melayu -yang-tidak-mendapat-sambutandi-pawagam-226335\%3famp=1

Heffron, J. (2012). The writer's idea book: How to develop great ideas for fiction, nonfiction, poetry and screenplays (10 ${ }^{\text {th }}$ anniversary ed.). Writer's Digest. (Karya Asal Diterbitkan 2000)

Kathryn, M. (2010). After the typewriter: the screenplay in a digital era. Journal of Screenwriting, 1(1), 11-25. https://doi.org/10.1386/josc.1.1.11/1

Knudsen, E. (2016). The Total Filmmaker: Thinking of screewriting, directing and editing as one role. New Writing, 13(1), 109-129. https://doi.org/10.1080/14790726.2016.1142571

Latifah. (2016). Penulis skrip lebih dirundung malang. Berita Harian. https://www.google.com.my/amp/s/www.bharian.com.my/amp/taxonomy/term/61/ 2016/03/136700/penulis-skrip-lebih-dirundung-malang

Mcgibbon, G. D. (2014). Seeing Double: The Process of Script Adaptation Between Theatre and Film. 18-32.

https://core.ac.uk/download/pdf/41338559.pdf

Peng, C. F., \& Nadaraja, S. (2014). Pelaksanaan Kemahiran Berfikir Kreatif Dan Kritis Dalam Pengajaran Dan Pembelajaran Komsas Di Sekolah Menengah. Jurnal Pendidikan Bahasa Melayu, 4(2), 10-24.

Tomaric, J. (2013). Filmmaking: Direct Your Movie from Script to Screen Using Proven Hollywood Techniques. Chapter 1. (pp. 7). Google Books. https://books.google.com.my/books?id=bGq1kecZRmcC\&printsec=frontcover\&dq=e+ book+free+script+film\&hl=en\&sa=X\&ved $=2$ ahUKEwjCtY3W-

KDxAhU5wjgGHfAODTI4ChDoATAJegQIChA C\#v=onepage\&q\&f=false

Tregde, D. (2013). A Case Study on Film Authorship: Exploring the Theoretical and Practical Sides in Film Production. Media Arts and Entertainment, 4(114), 5-13. https://www.elon.edu/u/academics/communications/journal/wpcontent/uploads/sites/153/2017/06/01DavidTregdeEJFall13.pdf

Xu, Y., Park, H., \& Baek, Y. (2011). A new approach toward digital storytelling: An activity focused on writing self-efficacy in a virtual learning environment. Educational Technology and Society, 14(4), 181-191.

Yang, J. (2019). Research on the artistic characteristics of VR films. Proceedings - 2019 International Conference on Virtual Reality and Intelligent Systems, ICVRIS 2019, 17, 5961. https://doi.org/10.1109/ICVRIS.2019.00023 DOI: $10.1109 /$ ICVRIS.2019.00023 
INTERNATIONAL JOURNAL OF ACADEMIC RESEARCH IN BUSINESS AND SOCIAL SCIENCES Vol. 11, No. 11, 2021, E-ISSN: 2222-6990 @ 2021 HRMARS

Zhu, X. (2020). Comparative analysis of film and tv in audience environment and audience psychology. Revista Argentina de Clinica Psicologica, 29(2), 1164-1173. https://doi.org/10.24205/03276716.2020.358 